\title{
BEYOND CENTERS AND CIRCLE TIME LEARNING IN EARLY CHILDHOOD (CASE OF RAUDHATUL ATHFAL) IN PAREPARE CITY
}

\author{
A. Fitriani Djollong ${ }^{1}$ \\ Hamdan Juhannis ${ }^{2}$ \\ Sulaiman Saat $^{3}$ \\ Andi Maulana ${ }^{4}$ \\ Postgraduate Program of UIN Alauddin Makassar ${ }^{1,2,3,4}$
}

\begin{abstract}
This article aimed to describe and evaluate the implementation of beyond centers and circle time learning in early childhood at Raudhatul Athfal in Parepare city. This study employed qualitative research with a phenomenological approach to observe and be directly involved in implementing Beyond Centers and Circle Time learning in early childhood at Raudhatul Athfal in Parepare City. The objects of this study were from Raudhatul Athfal UMDI Al Ihsan and at Raudhatul Athfal UMDI Ujung Baru Parepare City. The data collection methods used were observation, interviews, documentation, and triangulation. The validity testing of the data was carried out, namely internal validity, external validity and reliability. The study results indicate that the learning of beyond centers and circle time is one of the lessons aimed to meet the children's needs; it is carried out by serving the fun play to stimulate children's creativity and innovation with the support of the environment the learning process. This learning method is used to develop the children's life skills by using a footing that is implemented gradually and repeatedly so that the aspects of the children's development gain a comprehensive stimulus covering all aspects of development. Learning beyond centers and circle time is based on the growth and ability of the children, which aimed to form and develop an exploratory trait, shape and develop a creative trait, as well as form and develop an integral personality as outlined through directed, planned and fun play activities based on the tasks of child development according to the children's developmental stage.
\end{abstract}

Keywords: Beyond Centers Learning; Circle Time Learning; Early Childhood

\section{BACKROUND}

Beyond centers and circle time learning is an approach to the implementation of early childhood education that focuses on children with centered learning process in the play center and when the children are in a circle with four types of footing to support children's development, namely 1) the footing of the playing environment, 2) the footing before playing, 3) the footing during playing, and 4) the footing after playing.

Footing is the fickle support adapted to the development achieved by the children, which is provided as a basis for achieving higher development. Play centers are also called zones or children's play areas which are equipped with a set of playing equipment that served as the environmental footing needed to support children's development in three types of playing, namely 1) sensorimotor or functional play, 2) role 
play, 3) development play. When the circle is conducted, the educator sits with children in a circular position to provide a footing for them, which is done before and after playing. ${ }^{1}$ The important thing in learning beyond centers and circle time is playing intensity and density. The intensity of playing is the time required for a children's experience in the three types of playing throughout the day and year, while the density of play is the various ways of playing, which has several types of supporting the children's experience. ${ }^{2}$

Beyond centers and circle time learning emphasizes playing activities while learning in the learning centers; the children are allowed to play actively and creatively in the learning centers to develop their abilities to the fullest. The appropriate playing experience can optimize all aspects of the children's physical, cognitive, language, or social development. Early childhood requires educational stimulation, including spiritual, emotional, social, language, cognitive and psychomotor aspects. The development of these aspects will significantly influence the development process of the children in the future. The foundation of the importance of early childhood education is seen from an early age; the children must be equipped with knowledge such as various stimulants or stimuli.

The learning following the principles of early childhood learning and implemented through play activities are beyond centers and circle time learning. Early childhood education is an effort to optimally foster and develop all potentials aimed at children aged 0-6 years which is carried out by providing educational stimuli to help physical and spiritual growth and development so that the children have the readiness to enter further education, so the learning which is suitable for optimizing the learning process of early childhood is needed.

Early childhood education aims to develop all the potential of the children so that they can function as complete human beings according to the philosophy of a nation. Children can be seen as individuals who begin to know about the world. They do not yet know about manners, politeness, rules, norms and ethics. They are also learning to communicate with other people and understand other people. Children need to understand various things and natural phenomena to own the needed skills to live in society. Children's interactions with objects and other people are needed to develop noble personalities, character and morals. Early childhood is a valuable time to embed the values of nationalism, religion, moral ethics, and social values that are useful for the children's future.

Article 28 of the Law of the Republic of Indonesia No. 20 of 2003 concerning the National Education System states that early childhood education is provided for children from their newborn to the age of six, and it is not a prerequisite for attending primary education. Early childhood is a child in the age range of zero to six years. ${ }^{3}$ According to NAEYC (National Association Education for Young Children), early child-

\footnotetext{
${ }^{1}$ Departemen Pendidikan Nasional,'Pedoman Penerapan Pendekatan Beyond Centers and Circle Time (BCCT) (Pendekatan Sentra dan Lingkaran) dalam Pendidikan Anak Usia Dini, p. 2.

${ }^{2}$ Ratna Novita Punggeti, Model BCCT (Beyond Centers And Circle Time) Dengan Pendekatan Joyfull Learning Pada SD Kelas Awal Di Sumenep, Madura, Prosiding Seminar Nasional HDPGSDI Wilayah IV(2017), p. 115.

${ }^{3}$ Ahmad Susanto, Bimbingan dan Konseling di Taman Kanak-Kanak (Jakarta: Kencana Prenadamedia Group, 2015), p. 43.
} 
hood is a newborn to eight years old. ${ }^{4}$ A child in early childhood is a unique individual with characteristics of $0-6$ years old. ${ }^{5}$ A child is in the process of growth and development in terms of physical, cognitive, socio-emotional, language and motor aspects. It is called a golden age because, at this time, there is a sensitive period that only comes once. The sensitive period can be described as a situation where the children's character or potential is ready to develop.

Al-Qur'an reminds the faithful people to be afraid toward Allah SWT if they leave the poor children behind because of their worries about their welfare as Allah says in surah An-Nisa/4:9

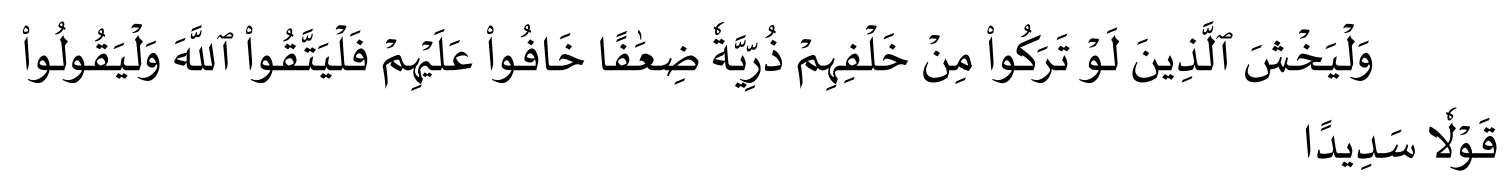

Meaning:

"Let the guardians be as concerned 'for the orphans" as they would if they were to 'die and' leave 'their own' helpless children behind. So let them be mindful of Allah and speak equitably."

The verse above implies that they should be worried about the fate of their children after their death. Do not let them become weak people both physically and spiritually and in terms of material and spiritual. They need careful preparation for nurturing by providing sufficient education to obtain the knowledge and skills to be used as provisions for life.

Early childhood is a group of children who lie in a unique process of growth and development because early childhood is the most delicate period to the stimulants that can affect the growth and development of children's physical and spiritual in the future. Allah SWT said in surah An-Nahl/16: 78 :

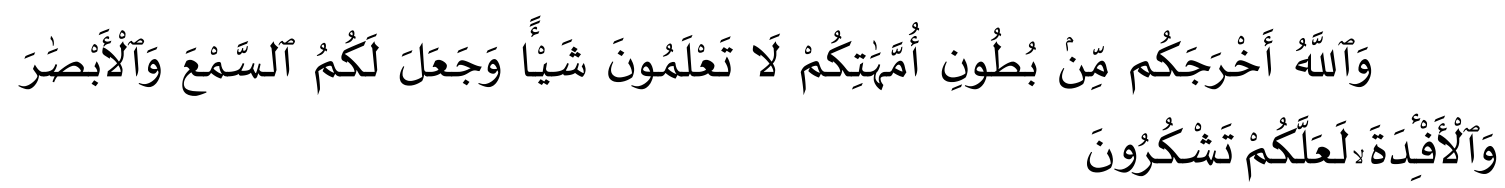

Meaning:

"and Allah brought you out of the wombs of your mothers while you knew nothing, and gave you hearing, sight, and intellect so perhaps you would be thankful." "

Based on the verse above, it is known that the children were born in a weak and helpless condition, and they have no knowledge of anything. Allah SWT gives hearing, sight and conscience (i.e. the mind which believed placed in the heart). Allah SWT teaches humans things previously unknown; after Allah SWT releases the human out of his/her mother's belly without understanding and knowing anything. Allah SWT grants humans with sense to understand and distinguish between good and bad things.

\footnotetext{
${ }^{4}$ Mansur, Pendidikan Anak Usia Dini dalam Islam (Yogyakarta: Pustaka Pelajar, 2005), p. 109.

${ }^{5}$ Trianto, Desain Pengembangan Pembelajaran Tematik (Jakarta: Kencana Prenada Media Group, 2011), p. 14.

${ }^{6}$ Kementerian Agama Republik Indonesia, Al-Qur'an dan Terjemahnya (Pustaka Agung Harapan, Surabaya, 2011), p. 133.

${ }^{7}$ Kementerian Agama Republik Indonesia, Al-Qur'an dan Terjemahnya, p. 484.
} 
Allah SWT opens humans' eyes to see the unseen things before and gives humans ears to hear voices so that some of them understand the talk, and also gives eyes to see various figures so that they can know and distinguish one another. Allah SWT brings out human babies through the birth process by mothers who carry them for approximately nine months with His power. Humans are born weak without knowing anything that they will be breastfed, cared for, raised, and given education by their mother to become solid and intelligent people.

Early childhood education is a form of education that focuses on laying the foundation of the physical growth and development (fine and rough motor coordination), intelligence (thinking power, creativity, emotional intelligence, and spiritual intelligence), socio-emotional (attitude, behavior, and religion) language and communication, following the uniqueness and developmental stages passed by early childhood. Early childhood education provides opportunities for children to develop their abilities and competencies from an early age under the stages and rhythms of children's development.

Early childhood is a unique period in children's lives because it is the most intense and busiest period of growth. Neither all the parents nor educators understand the right way to educate children at an early age. So children need a suitable environment to develop all of their potentials. Science has developed rapidly and is specialized. One of the sciences is early childhood education. Early childhood education discusses children aged 0-6 years old. Children of these ages are seen as having different characteristics from those older than them, so their education is necessary to be devoted. Early age is the golden period; children's rapid growth and development occur in early childhood. Early childhood is highly sensitive to acknowledging something; they always ask about what they see.

Raudhatul athfal is a formal education with the children's level at six years old or below. It is managed by Raudhatul athfal, which is equivalent to kindergarten. The curriculum emphasizes providing educational stimuli to help the physical and spiritual growth and development prepare to enter further education.

Raudhatul Athfal is one of the pre-school educational institutions. Government regulations regarding pre-school education have existed since 1990, but Raudhatul Athfal's name has not been included in it. Raudhatul Athfal, which is abbreviated as RA, is a form of early childhood education unit in the part of formal education which organizes educational programs with the specificity of Islam for children aged 4 (four) to 6 (six) years old. ${ }^{8}$

In implementing beyond centers and circle time learning at Raudhatul Athfal in Parepare City, there are still obstacles that hinder the implementation of beyond centers and circle time learning; as known, that obstacle can cause difficulties in the learning process. Learning activity at Raudhatul Athfal is done by playing. Playing is the demands and essential needs of early childhood in Raudhatul Athfal. Through playing, children can satisfy the demands and developmental dimensions of cognitive, motor, language, social, emotional and life attitudes. They are learning while playing or playing while learning has meaning for children.

There are several hindering factors in implementing learning beyond centers and circle time at Raudhatul Athfal, Parepare City, so various efforts were made to

${ }^{8}$ Mesiono, Manajemen Pendidikan Raudhatul Athfal, (Jakarta: Kencana, 2018), p. 2. 
overcome the obstacles. Efforts are defined as attempting activities that direct energy and thoughts to achieve goals. ${ }^{9}$ Efforts are the attempt to achieve goals. There are some efforts from Raudhatul Athfal of Parepare City to overcome the obstacles in the implementation of beyond centers and circle time learning, such as recruiting more educators, involving educators in scientific activities (seminars and workshops), holding activities that involve parents and the community, and striving for educational game tools that are balanced with the number of students.

Based on the background above, the researchers conducted a study on beyond centers and circle time learning in early childhood at Raudhatul Athfal in Parepare City.

The Qur'an is essentially revealed as a guide for humans to draw closer to Him, as we know that in the Qur'an it does not focus more on issues that have not been able to be understood by the mind so that they have not undergone development or change. So from this pattern we understand why the Qur'an will describe things that cannot be reached by the human senses, such as heaven and hell because these are problems that cannot be understood by reason. ${ }^{10}$ Some things will indeed be very difficult for humans to understand if they only rely on their knowledge of the senses and reason alone, because not all things in this world can be sensed, sometimes there are things that can only be believed by faith. ${ }^{11}$ So that human limitations should continue to strengthen our faith if there are still many things that we do not know and can only be known, then it is Allah Swt. who provides instructions in the form of data and explanations about these matters, among some of the most important ones related to eschatology, for example. doomsday, the grave, the mahsyar field to the concept of heaven and hell.

Not only matters related to eschatology that cannot be sensed by humans, but also the topics that are also universally described in it, namely: this matter becomes meaningful considering the urgency of the concept being interpreted, with an explanation that is directly mentioned in the Qur'an. so that it will really help us in an effort to understand, understand, describe and implement the universal principles that are the essence of existence and the urgency of this matter including the concept of deliberation. ${ }^{12}$

The question of deliberation will always be dynamic because this is not a matter related to eschatology, but is part of muamalah worship that helps humans in solving various kinds of problems. Allah SWT. bestowing the holy book al-Qur'an which will be a guide that accommodates all matters in general which are of a substance nature, while those which are accidental will be the responsibility of humans to develop them. Including in elaborating the issue of deliberation in the perspective of the Al-Qur'an. Even the Messenger of Allah. In providing benchmarks in deliberation, it is not rigid and explicitly explained. That is why, the method of practicing deliberation on the

${ }^{9}$ Departemen Pendidikan dan Kebudayaan, Kamus Besar Bahasa Indonesia (Jakarta: Balai Pustaka, 2002), p. 1250.

${ }^{10}$ Said, Muh. "Metodologi Penafsiran Sufistik: Perspektif Al-Gazali." Jurnal Diskursus Islam 2.1 (2014), h. 142-168.

${ }^{11}$ Amir, A., Khalid, M. R., Garancang, S., \& Kasim, A. "Bentuk-Bentuk Takrār dalam AlQur'an menurut Tinjauan Balagah (Studi Pada Juz Amma)”. Jurnal Diskursus Islam, 5(3), h. 498-526.

${ }^{12}$ M. Ka-anga, \& Hamzah, H. Metode Ijtihad Lembaga Majlis Agama Islam Provinsi Pattani Thailand Selatan. Jurnal Diskursus Islam, 7(2), h. 314-334. 
khalaufrrasidins are: Caliph Abu Bakr, Umar bin Khattab, Usman bin Affan, to Ali bin Abi Talib ra.

If we try to dissect the issue of deliberation, it has been substantively clearly described in the Qur'an, but it is necessary to understand that the explanations, interpretations, descriptions related to the deliberation issue actually come from the explanations of the companions, tabi'in and scholars. Given that it is very important to look at things from a contextual perspective, especially in the case of Deliberation, the researcher considers it important that it is important to reflect on how the Qur'an views deliberation in the review of Maudhu'iy interpretations. Therefore, it is related to the background of the problems that have been described. then the title of the paper that was raised was: Insights of the Qur'an on Deliberation (A Study of Maudhu'iy Interpretation).

\section{LITERATURE REVIEW}

\section{A. The Definition of Beyond Centers and Circle Time Learning}

Beyond centers and circle time learning is developed according to the needs of children to learn in learning centers. The center is a children's play area that aims to develop the full potential of children, where children play while learning. The games that children play will support their growth and development so that their growth and development optimally occur.

Beyond centers and circle time learning is intended to improve the practice of organizing early childhood education and the functions and duties of teachers in carrying out learning activities. The subjects of beyond centers and circle time learning are the children. It is used to develop their abilities according to their potential, and all the learning activities are done while playing. ${ }^{13}$ The teachers in beyond centers and circle time learning are expected to monitor each child's development stages according to their abilities. The assessment of children development is carried out individually; it refers to the distinct development for each child. Every child has developments that are different, both chronologically and biologically. For this reason, educators who have competence both academically and administratively are needed in transmitting knowledge to children. ${ }^{14}$ Beyond centers and circle time learning makes children active in their learning. The implementation of the learning involves children and the surrounding environment. Beyond centers and circle time learning use two learning environments: indoor materials in learning sheets and outdoor media. Those are the form of learning that seeks to introduce a natural environment that follows the learning material provided. ${ }^{15}$

Beyond centers and circle time learning is an approach that is carried out in early childhood which centered on the children whose learning process is in the play center, and when the child is in a circle, they use four things, namely (1) the footing of the playing environment, (2) the footing before playing, (3) the footing during play, and

\footnotetext{
${ }^{13}$ Ida Rindaningsih.Pengembangan Model Manajemen Strategik BerbasisBeyond Centers and Circle TimePAUD, Pedagogia 1, No. 2, (2012): p. 213-223.

${ }^{14}$ Mukhtar Latif, dkk, Orientasi Baru Pendidikan Anak Usia Dini, Teori dan Aplikasi, (Jakarta: Kencana, 2014), p. 4.

${ }^{15}$ Dadan Suryana, Pendidikan Anak usia Dini: Stimulasi dan Aspek Perkembangan Anak, p. 270.
} 
(4) the footing after playing. The center is a center for learning activities equipped with play tools that serve as the environmental footing needed to support children's development. The center is divided into three types of play, namely: (1) sensorimotor or functional play, (2) role play, and (3) construction play; each center consists of one development area that consisting of (1) preparation center, (2) play center of micro role, (3) play center of macro role, (4) block center, (5) faith and piety center, (6) natural ingredients center, (7) cooking center, (8) arts center. Beyond centers and circle time learning is given in the form of themes; the learning must be according to the theme, with moving classes every day from one center to another, the number of students in one class is 8-12 students accompanied by two educators.

Beyond centers and circle time learning focuses on children with centered learning process in the play center and when the children are in a circle with footing to support children's development. Circle time is the playing pattern where the educator sits with the children in a circular position to provide a footing before and after playing. The footing referred to the fickle supports according to the development achieved by the child. ${ }^{16}$

\section{B. The Advantages and Disadvantages of Beyond Centers and Circle Time Learning}

Beyond centers and circle time learning is intended to stimulate all aspects of children's intelligence to develop optimally; children's brains should continuously be stimulated to think actively by exploring their own experiences. If beyond centers and circle time learning is applied procedurally, consistently and sustainably, it could boost children's intelligence. Beyond centers and circle time learning are carried out in learning centers by carrying out activities following the learning objectives of the learning implementation plan. The learning activity is carried out by implementing footing, namely fickle supports to develop children's creativity and innovation.

The advantages and disadvantages of beyond centers and circle time learning are as follows:

1. The Advantages of Beyond Centers and Circle Time Learning Beyond centers and circle time learning has the advantage of boosting the potential of early childhood, including:

a) Beyond centers and circle time learning can maximally develop early childhood's full potential, including cognitive, socio-emotional, moralspiritual, physical, visual-spatial, natural and language aspects

b) Beyond centers and circle time learning could help the children become creative and innovative.

c) Learning becomes fun and full of meaning. The children are not bored with their learning because they regularly take turns studying in different centers; children are very enthusiastic, appreciative and dynamic in the learning process.

d) Children construct their knowledge and experiences.

e) The teachers teach the children to be independent in doing a job.

\footnotetext{
${ }^{16}$ Habibur Rahman, dkk, Model-Model Pembelajaran Anak Usia Dini Teori dan Implementasi (Yokyakarta: Ar-Ruzz Media, 2019), p. 312-313.
} 
f) The teachers teach the children to be responsible for their work.

g) The teacher teach the children to socialize because they would need it in collaborative play in the center

h) The teachers focus on mastering the learning process at the center where they are assigned. ${ }^{17}$

Beyond centers and circle time learning helps develop the full potential of the children so that they can grow and develop well, make the children become creative and innovative, help the children socialize, and teach them to be responsible so that their educational goals will be achieved maximally and optimally. The application of beyond centers and circle time learning is not rigid; it can be done in stages, corresponding to the local situations and conditions.

The advantages of beyond centers and circle time learning are 1) children would learn better if the environment is created naturally (naturalistic environment) 1) learning process become more meaningful (learning with meaning) if the children do the things they learnt instead of knowing the theory (learning by doing). 2) learning is more meaningful and effective. Learning is not only about paying attention to the educators and memorizing the learning material, but it also focuses on how the students should construct the knowledge on themselves. ${ }^{18}$

The advantage of beyond centers and circle time learning is that the curriculum is directed to build children's knowledge which is explored by themselves through various playing experiences in activity centers, thereby it could encourage the children's creativity, and the educators play the roles as the planners, supporters, and assessors of children's activities by conditioning each child to play an active role. Children development's stages are formulated in detail and clear way so that they can be used as a guide in assessing the children development, and the learning activities could be arranged in a precise sequence which starting from the arrangement of the playing environment to the arrangement of footing before, during, and after playing so that it can be used as a guide for novice educators. Beyond centers and circle time learning is not rigid, it could be done in stages, and if it suits the local situation and conditions, cooperation between students can be established. The learning process becomes more fun so that boredom can be avoided.

The curriculum of beyond centers and circle time learning is directed to construct the children's knowledge that they explore. The children are encouraged to play in activity centers. At the same time, the educators act as designers, supporters and assessors of children's activities. Learning is individualized, so the design, support, and assessment are customized to each child's developmental level and needs. The stages of children development are formulated in detail and clearly so that the teachers can have the guidelines in assessing the children development. The learning activities are arranged in a precise order. The setting of the playing environment entangles the distribution of footing. Every child gets support to be active, creative, and bold to make their own decisions. Each stage of childhood development is formulated as a reference for educators to assess children development.

\footnotetext{
${ }^{17}$ Nur Hamzah, Pelaksanaan Pembelajaran BCCT bagi Anak usia Dini : Studi Pelaksanaan BCCT di TK Islam Mujahidin Pontianak, Jurnal At-Turats Vol. 10. No. 2 2016. p. 129

${ }^{18}$ Phelps, P. Beyond Center and Circle Time: Scaffolding and Assessing the Play of Young Children. (Tallahassee, Florida: CCCRT. 2005). p. 23.
} 
Beyond centers and circle time learning can stimulate all aspects of children's intelligence (multiple intelligence) through directed play, learning settings that can stimulate the children to be active, creative, and keep thinking by exploring their own experiences. Children are encouraged to play in activity centers, while educators function as designers, supporters and assessors of children's activities. Learning is individualized, so the design, support, and assessment are customized to each child's developmental level and needs.

Beyond centers and circle time learning is not rigid; according to local situations and conditions, it can be done in stages. An excellent play environment for early childhood could support three types of play, namely sensorimotor play, which is an activity that uses gross and fine muscle movements and expresses all the senses of the body that get a sense of sensory function. Sensorimotor play can be seen when children perceive stimuli through their senses and produce movement as the response. Children play with objects to build perceptions; they need sensorimotor experiences because early childhood learns through their five senses and physical connection with their environment. Children's sensory needs can be supported by providing opportunities for children in several cases: 1 . when the children are allowed to move freely. 2 . If the children's play environment is suitable (indoor and outdoor). 3 . The children can correspond with many different textures and materials that can support each child's developmental needs. b. Role-play (macro and micro) is also known as symbolic plays, pretending, make-believe, fantasy or imagination. Role-play shows a child's higher thinking skills because the child has the experience she/he gets through the five senses and shows it more in pretending behavior. There are two types of role-playing; first, macro role play refers to the children playing with real-sized tools and can use them to create and play roles. For example, the children wear police uniforms with weapons. Second, micro role play refers to the children's situation with the small play materials. For instance, a child plays with a dollhouse: furniture and space. The development play aims to stimulate children's ability to turn their thoughts and ideas into tangible works. ${ }^{19}$

The children who work, find, and construct newly acquired latest knowledge and skills by themselves could make their thoughts more meaningful. Beyond centers and circle time learning could be the most appropriate method to create fun learning and develop active and creative thinking and responsibility. The application of beyond centers and circle time learning is flexible, not rigid; the implementation can be done in stages and customized to the school's situations and conditions. Beyond centers and circle time learning provides opport unities for children to play while learning in learning centers based on the theme.

\section{The Weaknesses of Beyond Centers and Circle Time Learning}

Beyond centers and circle time learning has weaknesses; it is not easy to implement compared to the conventional methods, which tend to be classical. It requires ample space due to several centers, requires sufficient time for children to play in the centers, requires facilities and infrastructure following the learning way itself, and requires many educators placed in the learning centers. The educators are required to be

\footnotetext{
${ }^{19}$ Pusat Pelayanan dan Informasi Terpadu PAUD, Tinjauan Anak, Pendidikan Anak Usia Dini (Paud), Dan Pendekatan "Beyond Centers And Circle Time”. p. 39-41.
} 
professional; they should have appropriate educational qualifications and must be able to prepare learning tools carefully.

Beyond centers and circle time learning is carried out by implementing a moving class system. It refers to the class changing or moving every day from one center to another in turns. The moving class system has weaknesses, those are:

a) The procurement of many classes and the equipment would cost higher than a single class, so the cost of education would be increased.

b) Transferring classes requires much time, so it demands the discipline of teachers and students so that they would not come late and reduce the learning time.

c) The change in the schedule would significantly affect the smoothness of the implementation in the learning process. ${ }^{20}$

Beyond centers and circle time learning requires enough space to open circles and serve the environmental footing materials. The learning centers should be suitable for the number of rooms. The children often snatch over the educational game tools because of the limited amount provided by education administrators.

Beyond centers and circle time learning entails the creativity and innovation from educators to design the learning activities at the center. The educators play a role as motivators and facilitators. However, the educators still have limitations in giving initiative and innovation to smooth the learning process. The educators still lack competence and quality in developing lesson plans; many educators still do not understand well how to prepare the learning implementation plans.

Beyond centers and circle time learning requires adequate educational game tools, and it should suit the ratio of the number of children in the school. The readiness and availability of educational game tools in schools provide opportunities for children to play games while learning optimally to support the growth and development of children as individuals who have their characteristics. On the other hand, the unavailability of adequate educational game tools will be one of the weaknesses of beyond centers and circle time learning. Incomplete and inadequate educational game tools will hinder the smoothness of the implementation in the learning process.

\section{RESEARCH METHOD}

This study employed qualitative research. Data collection methods used were observation, interviews, documentation, and triangulation. Validity testing of the data consisted of internal validity, external validity and reliability.

\section{IV.RESULT AND DISCUSSION}

\section{A. The Resistor Factors of the Implementation of Beyond Centers and Circle Time Learning in Early Childhood at Raudhatul Athfal, Parepare City}

Beyond centers and circles time learning is the learning that directs students to build the knowledge explored by themselves. Students are directed to play in learning

\footnotetext{
${ }^{20}$ Pusat Pelayanan dan Informasi Terpadu PAUD, Tinjauan Anak, Pendidikan Anak Usia Dini (Paud), Dan Pendekatan "Beyond Centers And Circle Time”. p. 44.
} 
centers. The orientation of beyond centers and circles time learning tends to direct the children's development towards optimal development, and the learning is carried out through playing because it can stimulate students' multiple intelligences. Beyond centers and circles time learning is equipped with various educational game tools as a medium for students to play in learning centers.

Based on the observation about the resistor factors of the implementation of beyond centers and circle time learning in early childhood at Raudhatul Athfaldi, Parepare City, it can be stated that:

\section{Raudhatul Athfal UMDI Al-Ihsan City of Parepare}

The results of the researchers' observations at Raudhatul Athfal UMDI AlIhsan City of Parepare, which conducted on Monday to Saturday, October 15-20, 2018, regarding the factors that hinder the implementation of beyond centers and circle time learning as follows:

a) Limited Classrooms;

Beyond centers and circle time learning requires a comprehensive and adequate space to support the successful implementation of beyond centers and circle time learning. The number of centers opened is adjusted to the number of rooms. Adequate facilities would unleash the learning process. A comfortable, safe, and peaceful atmosphere in the learning process would make the students active, innovative, and creative so that the growth and development of students could be optimal. The center arrangement consists of a room center and an outdoor center; these two centers can be arranged to become adjusted to establish the availability of space for the center. The critical thing in structuring the central space is the placement of areas and the types of play, which should be adjusted to the conditions and characteristics of the building and the school environment. The results obtained after observing the rooms' condition in this school are that Raudhatul Athfal UMDI Al-Ihsan City of Parepare has one quite spacious room arranged so that it becomes five small rooms. These five rooms utilize a cupboard as the border, and it is used as a place for students to study. The rooms consisted of; one room for the principal's room and four rooms for the center, namely the center for faith and piety, the arts center, the block center, and the preparation center, while the activities of natural materials center for learning held on every Saturday.

This school has implemented beyond centers and circle time learning in the learning process, and there are five centers opened, namely the center for faith and piety, preparation, blocks, arts and natural materials. This school has one spacious room divided into five small rooms, separated by a cupboard.The principal occupies one room, and four rooms are used for the center. Beyond centers and circle time learning requires space following the number of centers opened so that the students could move around freely when the room is large, but this school only have one spacious room which is used as a place for learning that is arranged in such a way that students in doing the learning activities can occupy it. ${ }^{21}$

The results of the researchers' observations can be concluded that Raudhatul Athfal UMDI Al-Ihsan City of Parepare in implementing behind centers and circle

\footnotetext{
${ }^{21}$ Asli, S.Pd.AUD, Teacher of Raudhatul Athfal UMDI Al Ihsan of Parepare City, Interview, on October 17, 2018.
} 
time learning has one quite spacious room that is separated by a cupboard so that it becomes five small rooms as a place for carrying out the learning process of students. Even though this school has limited space, the learning process could run due to the learning implementation plan. Classroom space limitations do not become an obstacle in carrying out the learning process; the learning process keeps occurring and is carried out according to the school's conditions. One room is well set so that the students can feel comfortable and safe in attending the learning activities at the center.

b) The Ratio of the Number of Educational Game Tools and Students is Not Equal

Educational game tools are games designed to provide a learning experience for the students. Educational game tools are the means that stimulate the activities of students so they can be motivated to learn something. It seems that the students play a game, but actually, the learning process is also involved. The selection of educational game tools needs to be designed considering the students' developmental characteristics and age gap. It is designed with noticing the level of security and safety for the students, and this educational game tool is designed to have various functions in supporting the implementation of the learning process and a fun learning process for the students. Beyond centers and circle time learning entails equipped educational game tools. Educational game tools are things that support the implementation of the learning process.

The results of the researchers' observations concerning the condition of the educational game tools at Raudhatul Athfal UMDI Al-Ihsan City of Parepare can be described that the number of educational game tools with the number of students are not equal; the number of game tools available in this school is still lacking in number. The number of educational game tools should be more plentiful than the number of students. The foundation's administrator keeps their efforts to provide educational game tools to support the implementation of the learning process so the number of students could be balanced with the number of educational game tools provided at this school so that the students could play with full of joy without fighting over the toys with other friends as a result of the limited number of educational game tools. The fulfillment of equipped educational game tools requires a large budget, while the schools have limited funds to provide them. The learning activity at the center should follow the daily learning implementation plan that educators have prepared by adjusting the condition of educational game tools available.

c) The Creativity and Innovation of Educators in Making Educational Game Tools is Still Lacking

Beyond centers and circle time learning requires equipped educational game tools and adequate learning facilities. Implementing beyond centers and circles time learning can run effectively and efficiently under the procedures of implementing beyond centers and circles time learning. The tools in educational games are designed to be used by students in activities carried out by playing while learning. Students undertake the playing activities, but the game contains elements of learning so that the growth and development of students take place optimally.

The results of the researcher's observations show that the procurement of educational game tools requires a large budget, but the ability of schools to provide educational game tools is minimal; schools have a limited budget to complete the education- 
al game tools. Due to the limited budget to complete the educational game tools, the foundation administrator and school principals are implementing various strategies. One of the strategies is making educational game tools from the scraps around. Using these materials is one way to overcome the limited budget for purchasing educational game tools. The tools in the educational game do not have to be purchased, but they can be made with simple materials; the materials are easy to find and can be made from scraps. Making educational game tools from scraps requires the creativity and innovation of educators. However, the educators at Raudhatul Athfal UMDI Al-Ihsan City of Parepare still have limitations of creativity and innovation in using scraps to make educational game tools. The educators do not own high motivation to learn about it. Besides, they do not have the opportunity to learn because of their other business. Making educational game tools by utilizing scraps requires high motivation, firm will, perseverance and patience from the educators. ${ }^{22}$

d) Parental Participation in Supporting the Implementation of Beyond Center and Circle Time Learning is Still Lacking

Educators and parents essentially have the same goal in children's education; they want to make the children pious, the children who could carry out the command and keep themselves away from Allah's prohibitions. Therefore, cooperation between educators and parents is essential and needed to educate, guide, foster jointly, and direct the children to become pious children. The participation and support of parents and stakeholders in implementing beyond centers and circles time learning is essential to embody the learning objectives. Parents and educators should establish good cooperation to optimize the growth and development of students. Parents should know every detail their child needs in the developmental stage to grow and develop optimally. Parents should be actively involved in the growth and development of their children at school to anticipate when any problems occur. The excellent interaction between educators and parents will establish a collaboration that can increase the students' activities in learning both at school and home.

Based on the observations, it can be explained that educators and parents at this school always establish good cooperation. Parents get information constantly about the development of their children and the problems they experience in the school environment. Regular meetings are held between educators and parents. Parents are invited to attend the regular meetings at school; it aims to inform the parents about the school's needs. The parents of students have a great concern about implementing the learning process in each center; it can be seen from their involvement and participation in the school activities to support the achievement of learning objectives at school. These parents' involvement in school activities motivates for educators to keep improving their abilities and competencies to educate and guide the students.

The researcher's observations show that foundation administrators often hold meetings with the educators and parents if there are essential things to be resolved, which is related to the education of students at Raudhatul Athfal UMDI Al-Ihsan, Parepare City. At the meeting, the school stakeholders conveyed about the condition of the students, and if they got the problem, it would be resolved together. The parents

\footnotetext{
${ }^{22}$ Asli, Teacher of Raudhatul Athfal UMDI Al Ihsan of Parepare City, Interview, on October $17,2018$.
} 
have realized that they must be involved in the school activities. Parents must establish good cooperation with the educators so that they would always get information about the progress of the growth and development of their child.

The observation regarding parental participation in supporting the implementation of beyond centers and circle time learning showed that all parties' involvement and support (educators, parents, stakeholders, education observers, the community, and the government) must be carried out. It is used to achieve the learning objectives in children's education, optimizing the growth and development of students so that they would become valuable humans for their religion, nation and state. The success of student education requires the cooperation and involvement of all parties to support every movement and step of the educators to achieve the learning objectives. Educators have given their best to educate and guide the students in schools, and parents should do the same thing so that the goals can be achieved optimally.

e) Broken educational game tool

Educators and students should maintain educational game tools to be durable; it is the obligation for both educators and students to care for them. However, sometimes when students play educational game tools, they ruin them.

According to the results of the researcher's observations, while doing activities at the learning center, the students are sometimes not careful in using the educational game tools to damage it. It would be fine if the damage of the educational game tool could be repaired, but it would take time if the game tool must be replaced because it is broken and cannot be repaired. The educational game tool itself is minimal, and if it is broken, it will become one of the obstacles in implementing the learning process. If the game equipment can be repaired, it will be repaired immediately, but if it cannot be repaired, the foundation administrator would try to replace it by buying the new one.

Based on the observations above, the researchers concluded that the damage to educational game tools was managed immediately by the principal and educators. The principal reports the broken game tool to the administrator to replace it with the new one because it cannot be repaired. Replacing damaged educational games requires coordination between the principal and the foundation administrator. Therefore, it is necessary to pay attention to the maintenance of educational game tools, and the educators always remind the students to be careful in using these educational game tools so that they can be durable and used for a long time. The principal and educators also need to consider the quality of purchasing the educational game tools to use for a long time.

\section{Raudhatul Athfal UMDI New End of Parepare City}

The researchers conducted this study at Raudhatul Athfal UMDI Ujung Baru City of Parepare from September 24, 2018, to September 29, 2018, regarding the factors that hindered the implementation of behind centers and circle time learning in early childhood at Raudhatul Athfal UMDI Ujung Baru City of Parepare. Based on the results of the researcher's observations, it shows that several things hinder the implementation of behind centers and circle time learning for early childhood at Raudhatul Athfal UMDI Ujung Baru City of Parepare as follows: 
a) Study space is still limited.

Implementing beyond centers and circle time learning requires classrooms based on the centers opened. One center requires one room. The arrangement of a limted space needs the creativity of educators to design the learning activity so that it can be carried out effectively and efficiently. The classrooms can be modified with small spaces called centers; one center consists of one development field such as the center for faith and piety, preparation, blocks, roles, arts and spiritual development.

The researcher's observations implied that Raudhatul Athfal UMDI Ujung Baru, Parepare City, has six centers: faith and piety, preparation, block, role, arts, and spiritual development centers. The centers should have one room for each, but this school only has four classrooms, one room used as an office and three rooms used as a learning center, because there are only four classrooms, while there are six centers opened. Based on the agreement with the foundation administrator, the preparation center, role center and block center are put in one room separated by a cupboard; this room is more expansive than the other rooms. Meanwhile, the arts center and the center for faith and piety occupy one room. This kind of arrangement could help implement beyond centers and circle time learning.

Based on these observations, the researcher can conclude that one of the factors that hinder the implementation of behind centers and circle time learning at Raudhatul Athfal UMDI Ujung Baru, Parepare City, is the limited amount of classrooms. Raudhatul Athfal UMDI Ujung Baru City of Parepare has four rooms; one room is used as an office, three rooms are used as the study area. The limited space is arranged in such a way so that the learning process can continue effectively and efficiently. Classroom arrangement is made as well as possible to feel safe, comfortable, and happy when they are in the learning center. Likewise, educators would feel motivated to guide and direct the students in various learning activities.

b) Limited stock of Educational game tools

Educational game tools are the things used as the means of playing for students in the learning process, and these play facilities contain educational value so that they can develop all the students' abilities to continue their education in elementary school. The application of beyond centers and circle time learning requires complete and adequate educational game tools as the means for students to experience the activity of play while learning in learning centers

Educational game tools should be provided as much as possible to meet the needs of students in learning in centers; it helps to support the achievement of learning objectives. The educational game tools should be suitable with the number of students so that when the learning process takes place at the center, students will not fight over the game tools; they do not need to wait for the other's turn to use the game tool.

Based on the researcher's observations, it can be explained that the tools for educational games in this school are still limited in stock, while in creating effective and efficient learning goals; an equipped educational game tool is needed. The educational game tools should be suitable for the number of students to not fight over the toys when they learn at the center. As in block center learning, the number of blocks in the school is not suitable for students, so the students commonly fight over the block game. Therefore, the educators usually do various ways to make the students not fight; for instance, they take turns using the toys. 


\section{Beyond Centers and Circle Time Learning in Early Childhood \\ (Case of Raudhatul Athfal) in Parepare City}

c) The educators have lack creativity in making educational game tools.

The teacher's role in beyond centers and circle time learning is only a facilitator, motivator and evaluator. Educators in behind centers and circle time learning are responsible for creating a real-world atmosphere in the classroom and encouraging students to link or connect their knowledge with their daily lives. Educators need to keep their effort to create the learning that can run naturally in the form of activities so that the students do not only know the knowledge taught by the teacher, but they also could learn by experiencing things.

The learning process in early childhood should be active, innovative, creative, practical and fun so that it could be easier for students to understand and comprehend the learning material well. Choosing the appropriate method and engaging learning media would also affect the pace and accuracy of students understanding and mastering the learning material presented by the teacher.

According to the researcher's observations, it can be explained that the educational game tools provided in schools are still limited due to the low budget of the school. On the other hand, the educational game tools used by students in the usual learning process could be broken at any time, so that if the tool cannot be repaired, it would be replaced with the new ones. They are reaching broken educational game tools with new ones requires budgets to purchase them. Whereas the source of the game tools might not only be from any stores but the scraps also can be used to make educational game tools. Therefore, the creativity and innovation of educators are needed to utilize used materials to make educational game tools. The educators at Raudhatul Athfal UMDI Ujung Baru City of Parepare still lack creativity in making educational game tools by utilizing scraps because the educators tend to have other activities. They have no motivation to learn how to make educational game tools from the scraps around them.

\section{d) Poor parental and community support}

Parents have a massive influence on the growth and development of children. Parents have a great responsibility for the achievement of educational goals. The parents' view towards their concern in their children's education is one of the success factors of education. Therefore, one of the ways for parents to provide education to their children is to send their children to school, and the educators would take over the responsibility of the children education in school. Therefore, the collaboration between parents and educators is an absolute must to optimize the growth and development of children.

According to the results of the researcher's observations, it can be explained that the obstacles experienced by schools are the poor support from parents and the community. Some parents have not understood the importance of early childhood education, so parents do not give their children the opportunity to enter early childhood education. The involvement of parents in school activities was still lacking. Some parents did not participate in school activities such as the meetings between educators and parents or competitions at school. The educators at schools understood that many parents of students were quite busy that they could not attend the activities held by the school. However, the children also have their behalf that their parents must understand and follow their child's development, so that if there are problems, they could follow them up immediately. 
e) Educational game tools decay.

Researchers' observations related to this issue can be explained that the maintenance and care of educational game tools is something that educators and students need to do so that educational game tools can last for a long time. However, when the students play in the learning center, there are broken educational game tools, so the tools must be repaired or even replaced. If the educational game equipment is broken and should be replaced, the school would apply for funds to the foundation, and the request for funds would be discussed first.

The decay of educational game tools is an unavoidable thing. Several factors caused the decay of educational game tools, namely, 1) the students were not careful in using educational game tools, so the educational game tools were broken. 2) the students also fought over the educational game tools and accidentally broke the game tools. 3) The school also did not know about the quality of the educational game purchased, so the game tool could not last long; it has not been used for a long time and has been broken. If there is a broken educational game tool, the school reports it to the foundation for a replacement; they would hold a meeting first because it is related to school financial expenses.

Educational game tools can facilitate the students to develop harmonious relationships with their friends because educational game tools can be played together. Therefore, educational game tools must meet the criteria designed for early childhood. The game tool can develop the various potentials of early childhood. The game tool does not harm early childhood, it is intended to improve creativity and activities of early childhood, and it has educational value and can produce something meaningful and valuable for early childhood.

\section{B. The Efforts to Overcome the Obstacle in the Implementation of Beyond centers and circle time Learning for Early Childhood in Raudhatul Athfal, Parepare City in 2016/2017}

The implementation of beyond centers and circle time learning for early childhood in Raudhatul Athfal, Parepare City, has been carried out by opening learning centers as a place for students to carry out play activities while learning related to the development of moral and religious values, physical motor development, cognitive development, language development, social-emotional development and artistic development.

\section{Raudhatul Athfal UMDI Al Ihsan City of Parepare}

The researchers conducted this study at Raudhatul Athfal UMDI Al Ihsan City of Parepare on October 15-20, 2018. The results of observations which related to the effort in overcoming the obstacles in the implementation of behind centers and circle time learning in early childhood in Raudhatul Athfal UMDI Al Ihsan, Parepare City, showed that the efforts of this school in overcoming the obstacles in the process of beyond centers and circles time learning are:

\section{a) Classroom arrangement}

The researcher's observations implied that implementing beyond centers and circles time learning at this school is carried out by designing one class into five rooms separated by cupboards or bookshelves. The room, separated by a cupboard or book- 
shelf, is made into five small rooms for central learning. One room is used for the principal's room; this room has a work desk, computer desk, cupboard for trophies, file cabinets and guest chairs. In contrast, the four rooms for learning centers are used for faith and piety, preparation, block, arts and natural materials. Each learning center has a desk and cupboard for educational game tools. The school's stakeholders attempt to not letting the limitations of the room would hinder the learning process; the existing rooms are well designed so that the learning process continues as planned in the learning implementation plan and students could feel safe, comfortable and happy to play while learning in the learning center so that the learning objectives can be achieved with the good results.

The room arrangement needs to be done before the learning process is carried out so that students can do the activities in the learning center effectively and efficiently to achieve the learning objectives. This room arrangement aims to make the students independent, disciplined, and responsible. It could also help the students make their own decisions, express ideas, and play games independently, in pairs and groups with others.

b) Budgeting for the procurement of educational game tools

The procurement of learning facilities and their equipment in schools is carried out in a meeting with the foundation administrator, school principals and teachers who discuss the school's needs and the budget needed to provide all the needs. The steps taken are 1) listing the urgent need, 2) estimating the budget needed for the procurement of school needs, 3) the purchase of urgent needs. The foundation's administrator and the principal attempt to reduce spending on the purchase of educational game tools prefer to make the educational game tools from scraps around, which would not cost much. The educational game tools in this school are not adjustable with the number of students yet. However, the foundation's administrator continues to provide the educational game tools based on the needs of students and the available budget.

The results of the researcher's observations described that the efforts of the foundation's administrator in order to improve the competence of educators in this school are to involve educators in such activities namely seminars, workshops, and training in order to gain knowledge, experience, broaden their horizons and develop the abilities of educators so that it can be applied well to the learning process. If the educator would join any scientific activities, the foundation administrator could defray half of the costs so that educators are not too burdened with the cost problem; this could stimulate the educators to participate in scientific activities.

Educators at Raudhatul Athfal UMDI Al-Ihsan City of Parepare, having a bachelor's degree, have fulfilled one of the requirements as educators who have competence, but the competence of these educators needs to be improved. Improving the competence of educators can be done by participating in scientific activities such as seminars, workshops, training, scientific discussions and other activities aimed at improving the competence of educators. These educator competencies need to be aligned with the development of scientific and technological progress.

The educators at Raudhatul Athfal UMDI Al-Ihsan City of Parepare, bearing the title of bachelor's degree, have fulfilled one of the requirements as educators who have competence, but the competence of these educators needs to be improved. Improving the competence of educators could be done by participating in scientific activities such as seminars, workshops, training, scientific discussions, and other activities 
aimed to improve the competence of educators. These educator competencies need to be aligned with scientific and technological progress.

c) Regular meeting with other schools

Regular meetings between schools are one of Raudhatul Athfal Al Ihsan's work programs, such as meetings between Raudhatul Athfal educators throughout the City of Parepare such as the Raudhatul Athfal Teachers Association under the auspices of the Ministry of Religion, Association of Indonesian Kindergarten Teacher (IGTKI). Educators must become members of the organization; even educators become the administrators of these organizations, and the meetings are held every month.

The results of the researchers' observations regarding this matter are that regular meetings between educators from other schools who are also members of the Raudhatul Athfal Teacher Association and the Association of Indonesian Kindergarten Teachers in Parepare City are held once a month. This routine meeting aims to establish the relationship between educators throughout the City of Parepare, and it aims to 1) Deliver the work programs, 2) Deliver information about the latest education, 3) Other information related to improving educator competencies and the quality of learning that is aligned with advances in science and technology. The regular meeting is expected to be a medium for exchanging knowledge and information regarding the development of the quality of the learning process, providing quality learning facilities, empowering educators and other information. This meeting is interspersed with the social gathering to captivate the educators to attend the meeting.

Regular meetings between Raudhatul Athfal as member of the Raudhatul Athfal Teachers Association and the Association of Indonesian Kindergarten organization in Parepare City are held once a month. This once a month routine meeting aims to 1) establish friendship, 2) exchange information related to learning, 3) help each other if there are schools that have any problems so that these problems can be solved quickly and accurately. The educators should work hand in hand, work together, help each other and have the vision to embody the educational goals. ${ }^{23}$

d) Execute the training to make educational game tools.

Procurement of educational game tools can be done in various ways; purchasing them is not the only way to own them. The scraps could be used to make some of the game tools. These used materials are easy to obtain, and the price is lower than buying educational game tools. Making educational tools from scraps is one of the efforts to save the budget so that the budget can be used for other needs.

The results of the researcher's observations showed that the utilization of scraps that are easily obtained in the surrounding environment is one of the solutions for making educational game tools. Making educational game tools from scraps requires the creativity and innovation of educators, so educators at this school attempt to hold training or practices with fellow educators in their schools or invite educators from other schools. The educators could use break time to gather and make the educational game tools from scraps. They obtain the information about making educational tools from the media, both print media and social media; educators continue to take

2018

${ }^{23}$ Ani, Teacher of Raudhatul Athfal UMDI Al Ihsan of Parepare City, Interview, on October 16, 


\section{Beyond Centers and Circle Time Learning in Early Childhood \\ (Case of Raudhatul Athfal) in Parepare City}

advantage of the advances in science and technology to learn how to make educational game tools from scraps.

e) Provision of regular meetings with the students' parents.

The collaboration between educators and parents is essential. Parents do not just send their children to school without caring about their children's condition at school. Parents should know what happens to their children at school, and educators need to tell parents about their children's condition. Cooperation between educators and parents needs to be done for the merit of the children themselves. Educators and parents are both obliged to make the students' learning successful; therefore, educators and parents must establish firm cooperation so that the learning objectives can be achieved optimally. ${ }^{24}$

The observation results showed that the regular meetings between educators and parents held once in three months to discuss the condition of the school and students to improve the quality of the school and increase the public interest in sending their children to this school unless there is an urgent matter to be resolved immediately, a meeting could be held aside from the predetermined schedule. Parents are very responsive and supportive of every step taken by this school. Parents feel valued so that parents are concerned about the activities carried out by the school. The involvement of parents in activities at school and the settling of any problems could positively impact this school.

It can be explained that the school in any activities always invites parents, and the regular meetings between educators and parents are held once in three months to discuss the development of students and the learning process. If there are problems related to students, parents are always involved in solving them. They are always ready to help, and as we know, the cooperation of educators and parents is needed, especially the negative influence in the advances of science and technology nowadays. The parents are worried that their children will be influenced to behave negatively. They are very responsive to the efforts made by the school.

Researchers can conclude that good cooperation between educators and parents would positively influence the quality of education; if all parties in education have good cooperation, it will improve the quality of education. The involvement of parents in schools' activities is one effort to improve the quality of education; parents need to know and obtain information about the development and behavior of their children at school so that the problems that occur can be anticipated as soon as possible so that the negative impacts could be decreased.

Ummahat DDI of Parepare City established several Raudhahtul Athfal scattered in the wards of Parepare City; it aims to educate the next generation who would continue the struggle of DDI organization in the fut ure and to assist the government in embodying the goals of national education. The response of parents and the community toward the vision is that they would send their children to Raudhatul Athfal because the learning process in this school is student-centered. It means that parents are now aware of the importance of education for early childhood. We, as the administrators, welcome the enthusiasm and high response from parents. We provide educational facil-

\footnotetext{
${ }^{24}$ Halimatussaddiah, Teacher of Raudhatul Athfal UMDI Al Ihsan of Parepare City, Interview, on October 15, 2018.
} 
ities and infrastructure, prepare learning tools, provide a variety of playing materials and educational game tools, prepare competent teachers, and all the things needed to improve our schools' quality; we prepared it all according to our abilities. We, as the administrators, would try our best to fulfill and provide the needs as soon as possible to improve the quality of education and to learn in our school. ${ }^{25}$

Giving the right stimulation for early childhood at their golden age of development would make the growth and development of children run optimally. Providing the optimal stimulation could be obtained by children in the early childhood education. Educational institutions have standards of teaching and educational staff who have gained knowledge about the children's growth and development and how to provide appropriate stimulation following the characteristics and rhythm of children's development. As the first and primary educators of their children, parents need to realize how important education is given to children from an early age. Early childhood is the golden age; therefore, stimulation is needed to experience optimal growth and development in their golden age.

\section{Raudhatul Athfal UMDI Ujung Baru of Parepare City}

Beyond centers and circle time learning is expected to run naturally in the form of activities aimed at to make children learn by experiencing, not just knowing the knowledge given by educators. The learning is child-centered, and the roles of the teacher only as a facilitator, motivator and evaluator. Besides, their roles are balancing cognitive, affective and psychomotor aspects to sharpen multiple intelligences and develop children's character holistically from an early age are the characteristics of beyond centers and circle time learning. Children's activities mainly occur at the play centers that function as interest centers with standard operating procedures and have a footing in the learning process. Students do the playing activities while learning at the learning center based on the themes planned in the lesson plan.

Researchers carried out this study at Raudhatul Athfal UMDI Ujung Baru City of Parepare on September 24-29, 2018. The results of the researchers' observations related to the efforts in overcoming the obstacle of the implementation of beyond centers and circle time learning at Raudhatul Athfal UMDI Ujung Baru City of Parepare are as follows:

a) Classroom arrangement based on the school conditions.

Raudhatul Athfal UMDI Ujung Baru City of Parepare continues to prepare all the facilities and infrastructure needed to implement learning beyond centers and circle time in the learning process at the center. Play activities in learning centers are the most appropriate medium for children's learning. Therefore, equipped facilities are needed to support the students in learning while playing to stimulate their minds to keep thinking actively by exploring their own experiences. The results of the researcher's observations showed that the arrangement of the room is one way to overcome the issue of limited space in this school so that all existing centers get adequate space. This school has six learning centres: faith and piety, preparation, block, role-playing, art, and spiritual development centers. The foundation administrator has arranged the

\footnotetext{
${ }^{25}$ Nuraini, Principal of Raudhatul Athfal UMDI Al Ihsan of Parepare City, Interview, on October $15,2018$.
} 
rooms, consisting of preparation center, role-playing center and block center, in one room. A cupboard separates these rooms because the room is quite large, so there are three learning centers. The art center is in one medium-sized room, the faith and piety center and the religious development center are put in one room. The limited space does not impede the implementation of the learning process at the center. However, the room is arranged in such a way that it could be occupied in implementing the learning process. ${ }^{26}$

The interviews with school principals indicated that the room arrangement was one of the efforts to overcome the limited space in this school so that the center's learning process could keep accomplished to embody the learning objectives. Procurement of additional space may no longer be carried out due to a lack of budget for the construction of new rooms. Room arrangement could become a solution to overcome the space limitations. Room arrangement refers to the arrangement of students' learning places to learn while playing in the provided room. A good room arrangement would make the students feel safe and comfortable, and it also supports the students in interacting with their environment and can develop students' independence. Although the room is small, it would have a good effect if it arranged adequately. Meanwhile, even if the room is large but not arranged correctly, it would not have a good effect. Therefore the arrangement of the room has to be done as well as possible. ${ }^{27}$

b) Provision of educational game tools

The observations of the researchers at this school indicated that the provision of educational game tools which adjustable with the number of students is kept to be pursued by schools under the supervision of foundation administrators; they take some steps such as 1) provide the educational game tools by purchasing some of the budgets is available. 2) Foundation administrators conduct training for educators to make educational game tools by utilizing scraps around because it is easy to find and could save the schools' budgets. 3) after conducting training for educators, the foundation administrator gives motivation and instruction to use scraps to make the educational game tools. 4) cooperating with the educational game tool companies to purchase good quality educational game tools at affordable and cheaper prices. 5) collaborate with parents of students to provide educational game tools by inviting parents to collect their children's unused toys but still worth using to be contributed to the school, and it is voluntary and based on the ability of each parent. The parents who do not have any are not forced to provide the educational game tools. On the other hand, some parents can buy new ones. Overall, all parents give an excellent response to this invitation.

Educational game tools at Raudhatul Athfal UMDI Ujung Baru of Parepare City still have limited stock in some learning centers, such as the block center. The number of available block games is not adjustable with the number of students so that sometimes students fight over the block toys. In overcoming this case, the educators

\footnotetext{
${ }^{26}$ Hamdanah, Teacher of Raudhatul Athfal UMDI Ujung Baru, Parepare City, Interview, on October 24, 2018.

${ }^{27}$ Berlian, Principal of Raudhatul Athfal UMDI Ujung Baru, Parepare City, Interview, on October 24, 2018.
} 
arrange for the students to use the block. The availability of adequate educational game tools would expedite the implementation of the learning process. ${ }^{28}$

c) Involve the educators in seminars, workshops, and training to improve educators' competencies

The results of the researchers' observations described the efforts of foundation administrators and school principals in increasing the educators' competence at Raudhatul Athfal UMDI Ujung Baru of Parepare City. Their effort such as 1) giving motivation and encouragement to educators so they can actively participate in scientific activities such as seminars, workshops, training, and other scientific activities that can improve the quality and competence of educators, if there is a fee, the foundation administrator will help by paying half of it. 2) holding and attending regular meetings actively with educators from other schools. The educators could establish friendships and a medium for exchanging information related to improving the quality of educators and learning methods. 3) Using the free time to read any information through print media, electronic media and social media so that educators can anticipate the advances of science and technology.

d) Hold meetings with the parents of students.

Based on the researchers' observations, it can be stated that the meeting with parents is held every three months at this school, but if there is something urgent and should be discussed through a meeting, the meeting can be held even though before the scheduled time. Support and involvement of parents in every activity implemented by the school has a positive impact on the development of this school; the meeting between educators and parents of students aims to 1) provide information to parents about their child's learning development. 2) as a meeting forum for educators and parents. The educators and parents should know each other, 3) convey the problems that occur in schools and seek the solutions to the problems, 4) convey the school needs that must be completed and provided.

Good cooperation between parents and educators needs to be carried out to help, respect, and make the information exchange about the implementation of education in schools easier for each other. The educators get the information about students' backgrounds, and parents could get information about the children's learning behavior and development at school. Good cooperation will facilitate the education of students so that their learning achievement could increase.

e) Making handmade educational game tools

The utilization of scraps that are easily found in the surrounding environment is one way to overcome the lack of educational game tools or the broken materials and playing tools that students have used. The educators make educational game tools from scraps such as boxes, paper, bottles, and cans to obtain the materials and game tools without purchasing them. Educators making their educational game tools from scraps could save the school budget. Therefore, educators must have creativity and in-

\footnotetext{
${ }^{28}$ Erna, Teacher of Raudhatul Athfal UMDI Ujung Baru, Parepare City, Interview, on October 27, 2018.
} 
novation in making the learning media or educational game tools from the scraps in the surrounding environment.

Based on the results of the researcher's observations, it can be described that the educators at this school are trying to make their educational game tools by utilizing the scraps around such as cans, boxes, plastic cups, bottles, and others. Before making the educational game tools from used scraps, the initial step from the educators is conducting the training or practice of making educational game tools by taking the time after the students go back from school. This training aims to give educators creativity and innovation to design and make educational game tools with a good quality that could vie with the purchased game tools.

The administrator of Ummahat DDI foundation always makes efforts to provide facilities and infrastructure, educational game tools and other materials needed for the smooth learning process and improving the quality of the Raudhatul Athfal schools so that parents and the community can send their children to this school. The foundation administrator realizes that equipped infrastructure and educational games are needed to implement beyond centers and circle time learning, but they keep their efforts to complete these facilities following their needs and abilities. Foundation administrator keeps providing the guide and motivation to educators to carry out their duties regularly even though facilities are still finite. ${ }^{29}$

Children should be allowed to pursue education, especially early childhood education. Early childhood education is a basic framework for students to adapt to the environment and further growth and development. The children should get some stimulation at an early age to develop their potential. Besides, the children are the next generation and the nation's successor. The role and cooperation of all parties from various circles such as parents, educators, the community and the government are needed to embody the goals of national education such as to educate the nation's life and develop the Indonesian people as a whole; namely, humans who believe and fear in God Almighty and have noble-minded character, knowledge and skills, physical and spiritual health, a solid and independent personality and a sense of social and national responsibility.

Raudhatul Athfal, as a pre-school education with Islamic characterization, has several aims in the school education path such as 1) lay the basis of the Muslim personality, develop attitudes, knowledge, skills and creativity needed by students in adapting to the environment, 2) development of growth and the students to achieve the goal of becoming a faithful human and have a fear to Allah SWT.

\section{CONCLUSION}

The inhibiting factors in the implementation of beyond centers and circle time learning in early childhood are 1) limited classroom facilities, 2) the ratio between the number of educational game tools and students is not balanced, 3) lack of competence of the educators, 4) educators are less creative in making educational game tools, 5) parental participation is still lacking 6) The broken educational game tools.

\footnotetext{
${ }^{29}$ Salmiah Aisyah, Teacher of Raudhatul Athfal UMDI Ujung Baru, Parepare City, Interview, on October 27, 2018.
} 
The efforts to overcome the obstacles of implementing beyond centers and circle time learning for early childhood are 1) classrooms arrangement that is suitable for school conditions. 2) Providing educational game tools. 3) Involve educators in seminars, workshops, and training to develop their abilities and increase their competence. 4) Hold regular meetings with other schools. 5) Hold training about making educational game tools by utilizing scraps, 6) conduct regular meetings with the parents of students.

\section{REFERENCE}

Departemen Pendidikan dan Kebudayaan. Kamus Besar Bahasa Indonesia. Jakarta: Balai Pustaka, 2002.

Departemen Pendidikan Nasional,'Pedoman Penerapan Pendekatan Beyond Centers and Circle Time (BCCT) (Pendekatan Sentra dan Lingkaran) dalam Pendidikan Anak Usia Dini.

Hamzah, Nur. Pelaksanaan Pembelajaran BCCT bagi Anak usia Dini : Studi Pelaksanaan BCCT di TK Islam Mujahidin Pontianak, Jurnal At-Turats Vol. 10. No. 2 2016. h. 129.

Kementerian Agama Republik Indonesia. Al-Qur'an dan Terjemahnya. Pustaka Agung Harapan, Surabaya, 2011.

Latif, Mukhtar, dkk. Orientasi Baru Pendidikan Anak Usia Dini, Teori dan Aplikasi. Jakarta: Kencana, 2014.

Mansur. Pendidikan Anak Usia Dini dalam Islam. Yogyakarta: Pustaka Pelajar, 2005.

Mesiono. Manajemen Pendidikan Raudhatul Athfal. Jakarta: Kencana, 2018.

Phelps. P. Beyond Center and Circle Time: Scaffolding and Assessing the Play of Young Children. Tallahassee, Florida: CCCRT. 2005.

Punggeti, Ratna Novita. Model BCCT (Beyond Centers And Circle Time) Dengan Pendekatan Joyfull Learning Pada SD Kelas Awal Di Sumenep, Madura, Prosiding Seminar Nasional HDPGSDI Wilayah IV (2017), h. 115.

Rahman, Habibur, dkk. Model-Model Pembelajaran Anak Usia Dini Teori dan Implementasi. Yogyakarta: Ar-Ruzz Media, 2019.

Rindaningsih, Ida. Pengembangan Model Manajemen Strategik Berbasis Beyond Centers and Circle Time PAUD, Pedagogia 1, No. 2, (2012): h. 213-223.

Suryana, Dadan. Pendidikan Anak usia Dini: Stimulasi dan Aspek Perkembangan Anak.

Susanto, Ahmad. Bimbingan dan Konseling di Taman Kanak-Kanak. Jakarta: Kencana Prenadamedia Group, 2015. 
Beyond Centers and Circle Time Learning in Early Childhood (Case of Raudhatul Athfal) in Parepare City

Trianto. Desain Pengembangan Pembelajaran Tematik. Jakarta: Kencana Prenada Media Group, 2011. 